\title{
LOCAL ANTI-RHEUMATIC EFFECTIVENESS OF HIGHER ESTERS AND ANALOGUES OF HYDROCORTISONE* ${ }^{*}$
}

\author{
JOSEPH L. HOLLANDER, ERNEST M. BROWN, JR., RALPH A. JESSAR, \\ LOUIS UDELL, NATHAN SMUKLER, and MORRIS A. BOWIE \\ From the Arthritis Section, Department of Medicine, Hospital of the University of Pennsylvania, \\ Philadelphia, $\mathrm{Pa}$
}

(RECEIVED FOR PUBLICATION OCTOBER 4, 1954)

During the past $3 \frac{1}{2}$ years we have given more than 17,000 intrasynovial injections of hydrocortisone (Compound F) into the joints, bursae, or tendon sheaths of nearly 1,300 patients for various forms of rheumatic disease (Hollander and others, 1951a, 1954; Brown and others, 1953; Hollander, 1953a,b). Numerous confirmatory and supplementary reports in the world medical literature have shown that this method has now been widely accepted as an adjunct in the local management of arthritis and related conditions (See Bibliography).

While we have found that intra-articular hydrocortisone acetate $(\mathrm{F}$ a) produces a temporary alleviating effect in over 80 per cent. of all joints injected, the transitory nature of this effect limits its practical value as therapy in about one-third of our cases. Obviously, joint injections cannot be repeated every few days, even on hospitalized patients. Since the method has proved of value mainly in helping to preserve normal joint function in ambulatory patients who would otherwise be disabled by some local rheumatic inflammation, a search has been conducted to find an agent capable of prolonging the local palliative effect.

Investigations into the disappearance of hydrocortisone from the synovial fluid, which revealed the absorption of the injected hormone by the cells of the synovial fluid and particularly by the lining membrane of the synovium, were reported by us a year ago (Hollander, 1953c, Zacco and others, 1954). The most significant finding was that the hydrocortisone acetate was apparently absorbed and retained by the lining of the synovium without splitting the ester, whereas unabsorbed hormone remaining in the joint fluid was rapidly hydrolysed and broken down.

We therefore assumed that higher, and less

* Read before the Annual Meeting of the American Rheumatism Association, San Francisco, Cal., June 18, 1954. See p. 354 of this issue.

$\dagger$ Supported by grants from the Helon Augusta Parkhill Memorial Fund, and from Merck and Co., Inc. soluble, esters of hydrocortisone would likewise be absorbed unchanged by the synovial membrane, and might have a longer anti-inflammatory effect. Sterile microcrystalline suspensions of such higher esters and some analogues of hydrocortisone were formulated for us in the laboratories of Merck and Co.

\section{Method}

Our method of comparing the relative effectiveness of the various hydrocortisone esters has been simple. Patients with rheumatoid arthritis, or osteo-arthritis, who had previously been receiving periodic $\mathrm{F}$ a injections into an arthritic knee were studied exclusively. No change was made in general supportive or systemic therapy for the arthritis during the period of comparison. Since all the preparations appeared identical in the syringe, it was easy to keep the knowledge of any substitution from the patient. All comparisons were based on identical doses of hormone. Follow-up examinations were made on each patient to determine the extent and duration of the ameliorative effect of the injection on the symptoms and signs of the inflamed and painful joint. The effects were recorded and compared with similar observations made after $\mathrm{F}$ a injections. If comparative effects were equivocal, subsequent injections alternating the two preparations were carried out. In a few cases where both knees were about equally inflamed, simultaneous comparisons were possible. While most cases chosen were those having a transitory effect from hydrocortisone acetate, some others having had a relatively long effect were also studied.

The preparations thoroughly studied included two analogues of hydrocortisone: 9-alpha-chloro hydrocortisone (9-a-c F), and allo-dihydro hydrocortisone (A-d F). In addition to the standard hydrocortisone acetate $(\mathrm{F} a)$, we also studied hydrocortisone tertiary butyl acetate ( $\mathrm{F} \mathrm{t}-\mathrm{B} \mathrm{a}$ ), hydrocortisone caprylate (F Cap.), and hydrocortisone benzoate (F Benz.). Others are still being assayed.

\section{Results}

The largest series was one of 171 cases of rheumatoid arthritis or osteo-arthritis (about equal numbers 
of each) in which hydrocortisone tertiary butyl acetate was substituted for hydrocortisone acetate. Comparative results, summarized in Table I, varied tremendously both in degree and in the duration of the alleviating effect. Of the 171 cases, 111 (65 per cent.) demonstrated greater alleviation of symptoms and signs from $\mathrm{F} \mathrm{t-B} \mathrm{a,} 51$ (30 per cent.) showed no appreciable difference, and in nine ( 5 per cent.) the action of the higher ester was inferior to that of the standard $\mathrm{F}$ a.

TABLE I

COMPARATIVE EFFECTIVENESS OF INTRA-ARTICULAR HYDROCORTISONE TERTIARY BUTYL ACETATE AND HYDROCORTISONE ACETATE

\begin{tabular}{|c|c|c|c|c|c|}
\hline Result & . & $\underset{\text { Superior }}{\mathbf{F} \text { t-Ba }}$ & $\begin{array}{l}\mathbf{F ~ t}-\mathbf{B a} \\
=\mathbf{F} \text { a }\end{array}$ & $\underset{\text { Superior }}{\mathbf{F} \text { a }}$ & Total \\
\hline \multirow{2}{*}{$\begin{array}{c}\text { Degree of } \\
\text { Clinical } \\
\text { Improvement }\end{array}$} & No. of Cases & 111 & 51 & 9 & 171 \\
\hline & Percentage & 65 & 30 & 5 & 100 \\
\hline \multirow{2}{*}{$\begin{array}{c}\text { Duration of } \\
\text { Clinical } \\
\text { Improvement }\end{array}$} & No. of Cases & 101 & 59 & 11 & 171 \\
\hline & Percentage & 59 & 35 & 6 & 100 \\
\hline
\end{tabular}

Much more easily measured was the duration of relief after injections. By this we found that in 101 cases (59 per cent.) the duration of effectiveness was increased by at least 3 days, and was often multiplied from two to ten times by $\mathrm{Ft}$ t-B a as compared with $\mathrm{F}$ a. In 59 cases ( 35 per cent.) no significant difference in effect was noted, and in eleven cases ( 6 per cent.) $F$ t-B a produced a shorter period of relief than $F$ a.

By the simple method of adding together total days of symptomatic relief in all 171 cases after one injection each of hydrocortisone acetate (total 1,578) and then dividing by 171 , we found the average duration of effectiveness after each was 9 days. Repeating this with the data from cases injected with hydrocortisone t-butyl acetate (total 2,745 ) we found the average duration of effectiveness from each injection to be 16 days.

There were four (2.3 per cent.) post-injection exacerbations of symptoms in the treated joint following $\mathrm{Fa}$ in this series, and three $(1.8 \mathrm{per}$ cent.) following $\mathrm{F} \mathrm{t}-\mathrm{B}$ a injection. This difference is probably not significant.

Using the more easily measured, and apparently more critical, duration of effectiveness as a criterion for comparison, we assayed the relative effectiveness of other analogues and esters of hydrocortisone in seventeen patients with rheumatoid arthritis. Table II shows how variable the comparative duration of response can be after the injection of any of the preparations. The 9-alpha-chloro hydrocortisone (9-a-c F, col. 1) produced an average of 8 days' relief, as compared with 6 days from hydrocortisone acetate in the same joints (col. 3). Allo-dihydro hydrocortisone (A-d F, col. 2) produced no alleviation in eleven cases, a transient response in five, $\frac{\square}{0}$. and alleviation of symptoms in one joint for 6 days. Therefore, the average period of effect was less than $\overrightarrow{\vec{F}}$ 1 day following this preparation. In these seventeen patients the hydrocortisone t-butyl acetate (col. 4) $\frac{\mathrm{C}}{0}$ produced from 6 to 30 days alleviation (average 12). Hydrocortisone caprylate (F Cap., col. 5) averaged $\Phi$ little better than $\mathrm{Fa}$ ( 7 days), though in two instances the alleviation was longer than that ${ }^{\infty}$ obtained from any other injected preparation. The $\vec{O}$

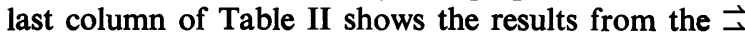
injection of hydrocortisone benzoate (F Benz.). $\stackrel{\omega}{\sim}$ While the duration of effect in nine cases averaged 8 days, further trial was abandoned because of the $?$ high incidence of rather severe post-injection $\vec{\omega}$ reactions (indicated by $r$ ) in the injected joints, $\vec{\sim}$ which meant that the preparation itself was an irritant.

TABLE II

DURATION OF EFFECT FROM 9-ALPHA-CHLORO HYDROCORTISONE, ALLO-DIHYDRO HYDROCORTISONE, HYDROCORTISONE, ALLO-DIHYDROHYDROCORTISONE, HYDROACETATE, HYDROCORTISONE CAPRYLATE, AND HYDRO- ণ CORTISONE BENZOATE INJECTED INTRA-ARTICULARLY INTO SEVENTEEN RHEUMATOID ARTHRITIC KNEES

\begin{tabular}{|c|c|c|c|c|c|c|}
\hline Case & 9-a-c F & A-d F & $\mathbf{F ~ a ~}$ & F t-Ba & F Cap. & F Beng \\
\hline $\begin{array}{l}\mathbf{a} \\
\mathbf{b} \\
\mathbf{c} \\
\mathbf{d} \\
\mathbf{e} \\
\mathbf{f} \\
\mathbf{g} \\
\mathbf{h} \\
\mathbf{i} \\
\mathbf{j} \\
\mathbf{k} \\
\mathbf{l} \\
\mathbf{m} \\
\mathbf{n} \\
\mathbf{o} \\
\mathbf{p} \\
\mathbf{q}\end{array}$ & $\begin{array}{r}6 \\
7 \\
6 \\
7 \\
11 \\
8 \\
10 \\
4 \\
9 \\
9 \\
7 \\
11 \\
6 \\
2 \\
9 \\
7 \\
8\end{array}$ & $\begin{array}{l}0 \\
0 \\
0 \\
0 \\
0 \\
0 \\
0 \\
2 \\
0 \\
0 \\
6 \\
0 \\
0 \\
2 \\
1 \\
1 \\
1\end{array}$ & $\begin{array}{c}4 \\
10 \\
6 \\
2 \\
14 \\
7 \\
8 \\
2 \\
7 \\
10 \\
2(r) \\
4 \\
5 \\
2 \\
5 \\
8 \\
9\end{array}$ & $\begin{array}{r}9 \\
9 \\
6 \\
6 \\
14 \\
14 \\
13 \\
4 \\
12 \\
30 \\
11 \\
14 \\
7 \\
7 \\
14 \\
8 \\
12\end{array}$ & $\begin{array}{c}3 \\
3 \\
6 \\
1 \\
14 \\
16 \\
4 \\
8 \\
13 \\
5(r) \\
718 \\
2 \\
0 \\
8 \\
0\end{array}$ & $\begin{array}{l}11(1) \\
\frac{3}{3} \\
\frac{10}{14} \\
\frac{1}{1}(r) \\
4(r) \\
\frac{7}{14} \\
7 \\
7(r)\end{array}$ \\
\hline $\begin{array}{l}\text { Average } \\
\text { No. of } \\
\text { Days }\end{array}$ & 8 & 1 & 6 & 12 & 7 & 8 \\
\hline $\begin{array}{l}\text { Duration } \\
\text { Quotient* }\end{array}$ & $1 \cdot 3$ & $0 \cdot 16$ & $1 \cdot 0$ & $2 \cdot 0$ & $1 \cdot 16$ & $1 \cdot 3$ \\
\hline
\end{tabular}

Average number of days of effect from Fx divided by the average number of days of effect from $F$ a.

(r) Initial exacerbation occurred after injection, then days of improvement followed as indicated.

As a ready means of comparing effectiveness of $\underset{N}{N}$ the various hydrocortisone preparations, the average $\%$ number of days of beneficial effect from injection of $N$ each preparation is divided by average days of benefit $\mathrm{N}$ following injection of the "standard" hydrocortisone 으 acetate, to reach what we have termed a "duration quotient". This figure shows the superiority of hydrocortisone t-butyl acetate to the other prepara- $\stackrel{\infty}{?}$ tions. 


\section{Discussion}

While the mode of action of hydrocortisone at the tissue level is still unknown, it might at first appear from the results that our original premise is borne out. Whether the longer duration of benefit resulting from the intra-articular injection of hydrocortisone t-butyl acetate is merely due to its being a less soluble preparation, thus leading to slower tissue utilization, remains to be determined. If solubility alone were the factor determining length of action, then other higher esters of hydrocortisone, likewise much less soluble than the acetate, should have at least a comparable effect. But such was not the case.

Why hydrocortisone t-butyl acetate produces a longer period of palliation in a mere majority of cases, and shows no advantage over the acetate in others, cannot be adequately explained. It seems peculiar that in certain individuals the injection of hydrocortisone caprylate produced an amelioration of arthritis superior both in degree and duration to any of the other preparations studied. This superiority was repeatable consistently in these cases, yet in most others this preparation proved inferior to the rest. A few other such inconsistencies appeared on using other preparations. May it be that the synovial membranes of individuals differ in ability to absorb and utilize certain hydrocortisone preparations? Since the degree and duration of palliation obtained from hydrocortisone injection have no correlation with the intensity or length of existence of the synovial irritation, or even indeed with the type of arthritis present, the answer is certainly not yet forthcoming.

One fact, however, does emerge from these studies. In most arthritic individuals the intra-articular injection of certain analogues or higher esters of hydrocortisone can amplify both the degree and duration of the local hormone effect. The way is, therefore, open to finding other analogues or esters of hydrocortisone having a still more lasting palliative effect, which should render intra-articular hydrocortisone therapy of greater practical value as an adjuvant in the local management of a variety of rheumatic conditions.

\section{Summary}

(1) Hydrocortisone t-butyl acetate (F t-B a) injected intra-articularly into the arthritic knees of 171 patients has produced a greater and longer lasting palliation than identical doses of hydrocortisone acetate ( $F$ a) in about 60 per cent. of patients. In about 35 per cent. of cases no advantage was noted, and in about 5 per cent. the hydrocortisone acetate was more effective.
(2) By similar comparison, two analogues of hydrocortisone, i.e. 9-alpha-chloro hydrocortisone (9-a-c F), and allo-dihydro hydrocortisone (A-d F), and two other higher esters, i.e. hydrocortisone caprylate (F Cap.), and hydrocortisone benzoate (F Benz), were clinically assayed in seventeen cases of rheumatoid arthritis. While benefit was increased in a few cases by one or another of these preparations, none gave such consistent improvement as hydrocortisone t-butyl acetate. In fact, the hydrocortisone benzoate proved impracticable because of synovial irritation, and the effect of the allo-dihydro hydrocortisone was markedly inferior to that of the hydrocortisone acetate in most cases.

(3) While the reason for the greater effectiveness in the local palliation of arthritic symptoms of certain higher esters of hydrocortisone remains unknown, the way appears open towards the discovery of even more effective hydrocortisone preparations for intra-articular use in the rheumatic diseases.

\section{AdDENDUM}

Since this report was originally prepared and presented, we have had the opportunity of assaying 9-alpha-fluoro hydrocortisone acetate (9-a-f F a) intra-articularly in 37 cases of rheumatoid arthritis or osteo-arthritis. A local anti-inflammatory effect was noted clinically from an intra-articular injection as small as $3 \mathrm{mg}$., but in most cases $5 \mathrm{mg}$. was used. Although the effective dose was decidedly smaller, the benefits in no case exceeded that of hydrocortisone acetate in degree of palliation or in duration of effect, and the duration quotient was less than 0.5. Whenever the dose was increased to $7.5 \mathrm{mg}$. into one knee, or $5 \mathrm{mg}$. into each knee, marked oedema of the leg or legs appeared and persisted for several days even though the patient was receiving no systemic cortisone.

Our findings thus confirm the marked increased anti-inflammatory potency of 9-alpha-fluoro hydrocortisone acetate noted by Boland and Headley (1954), and the increased salt retention noted by Liddle and others (1954). This latter effect would seem to nullify the advantage of the increased potency, at least for intra-articular use.

\section{REFERENCES}

Brown, E. M., Jr., Frain, J. B., Udell, L., and Hollander, J. L. (1953). Amer. J. med., 15, 656.

Hollander, J. L. (1953a). J. Bone Jt Surg., 35A, 983.

(1953b). Ann. intern. Med., 39, 735

(1953c). Annals of the Rheumatic Diseases, 12, 347.

Brown, E. M., Jr., and Jessar, R. A. (1954). Med. Clin. N. Amer., 38, 349.

$-\frac{}{-}$, and Brown, C. Y. (1951a). J. clin. Invest., 30, 650. M., Richardson, E. M., Crittenden, J. O., Hollander, J. L. and Dohan, F. C. (1954). J. clin. Endocr., 14, 711. 


\section{ADDITIONAL BIBLIOGRAPHY}

Ballabio, C. B., Sala, G., and Bonomo, E. (1953). Reumatismo, 259.

Bauer, J. (1954). Münch. med. Wschr., 96, 309.

Bilka, P. J. (1952). Minn. Med., 35, 938.

Boland, E. W. (1952). Calif. Med., $77, \mathrm{i}$.

-, and Headley, N. E. (1954). Annals of the Rheumatic Diseases, 13, 291.

Böni, A. (1953). Praxis, 42, 702.

Bornstein, J., Silver, M., Neustadt, D. H., Berkowitz, S., and Steinbrocker, O. (1954). Geriatrics, 9, 205.

Breck, C. A., and Breck, R. W. (1952). Meriden Hosp. Bull., 6, 39. Brown, L. (1953). S. Afr. med. J., 27, 226.

Butson, A. R. C. (1954). Canad. med. Ass. J., 70, 51.

Copeman, W. S. C., Savage, O., Dodds, C., Glyn, J. H., and Fearnley, M. E. (1954). Brit. med. J., 1 , 1109.

Coste, F., Piguet, B., and Civatte, J.'(1953). Presse méd., 61, 1157.

Coventry, M. B. (1954). Proc. Mayo Clin., 29, 58.

Cozen, L. (1953). Postgrad. Med., 14, 59.

Cyriax, J., and Troisier, O. (1953).' Brit. med. J., 2, 966.

Davison, S. (1953). N.Y. St. med. J., 53, 975.

Dixon, A. St. J. (1954). Lancet, 2,281 .

Duff, I. F., Robinson, W. D., and Smith, E. M. (1951). J. Lab. clin. Med., 38, 805.

Ensign, D. C., and Sigler, J. W. (1952). J. Mich. med. Soc., 51, 1189.

Francon, J. (1953). Presse therm. clim., 90,170 .

Françan, J. (1953). Presse therm. clim., 90, 170.

Freiberg, J. A. (1954). Postgrad. Med., 16, 104.

Freund, H. A. (1952). J. Mich. med. Soc., 51, 1199

Henderson, E. D., and Henderson, C. C.'(1953). Minn. Med., 36, 142 .

Henriksen, E., and Nyfos, L. (1953). Ugeskr. Laeg., 115, 1763.

Hollander, J. L. (1951). Bull. rheum. Dis., No. 2, p. 3.

Hollander, J. L. (1951). Br., Jessar, R. A., and Brown, C. Y. (1951b). J. Amer. med. Ass., 147, 1629.

Howard, L. D., Jr., Bunnell, S., and Pratt, D. R. (1953). J. Bone Jt Surg., 35Ä, 526.

Hurlburt, F. W. B., and Robinson, C. E. G. (1954). Canad. med. Ass. J., 70, 645.

Jessar, R. A., Ganzeli, M. A., and Ragan, C. (1953). J. clin. Invest., 32, 480 .

Kashtan, H. A. (1952). Harper Hosp. Bull., 10, 143.

Kersley, G. D., and Desmarais, M. H. L. (1952). Lancet, 2, 269.

Krewer, B. (1954). Presse méd., 62, 543.

Lancet (1954). Leader, 1, 448.

Liddle, G. W., Pechet, M. M., and Bartter, F. C. (1954). Science, $120,496$.

Losada, M., and Zanartu, J. (1953). Rev. med. Chile, 81, 261.

Mahaffey, H. W. (1954). J. Amer. med. Ass., 156, 312

Mettier, S. R. (1954). Gen. Pract. Clin., 10, 89.

Mettier, S. R. (1954). Gen. Pract. Clin.,

Norcross, B. M. (1954). N.Y. St. J. med., 54, 347.

Orbach, E. J. (1952). J. int. Coll. Surg., 18, 159.

Pap, L. de, and Teixeira, M. A. (1953). Rev. Rhum., 20, 285

Price, A. E., Reveno, W. S., Lightbody, J. J., Heide, E. C. V., Kashtan, H. A., and Corrigan, K. E. (1952). J. Mich. med. Soc., $51,1183$.

Quin, C. E., and Binks, F. A. (1954). Lancet, 2, 221.

Quigley, T. B. (1954). New Engl. J. Med., 250, 188.

Ramsey, R. H., and Key, J. A. (1953). Missouri Med., 50, 604.

Reynolds, F. C., and Ramsay, R. H. (1954). Sth. med. J. (Bgham Ala.), 47, 209.

Robecchi, A., and Capra, R. (1952). Minerva med. (Torino) (Parte sci), 43 (2), 1259.

Tact (1953). Ibid., 44 (1), 997.

Sacks, S. (1953). S. Afr. med. J., 27, 224

Sèze, S. de, Robin, J., Chevallier, J., and Françon, J. (1952a). Presse méd., 60, 1465

- - _ - (1952b). Rev. Rhum., 19, 985.

68, 1045 .

(1952c). Bull. Soc., méd. Hôp. Paris,

and Debeyre, N. (1953). Rev. Rhum., 20, 298.

-, and Denis, A. (1953). Ibid., 20, 303.

Shaw, C. C. (1954). Postgrad. Med., 15, 308.

Stein, I., Stein, R. O., and Beller, M. L. (1953). Amer. J. Surg., $86,123$.

Steinbrocker, O. (1953). Indust. Med. Surg., 22, 314.

Stevenson, C. R., Zuckner, J., and Freyberg, R. H. (1952). Annals of the Rheumatic Diseases, 11, 112.

Weismann-Netter, R., Levy, R., and Lorch, P. (1954). Presse méd., 62, 852

Weiss, T. E., Duncan, T., and de la Cruz, B. (1954). J. med. Ass. Georgia, 43, 629.

Wilson, H. Fairbanks, R., and Scialabba, D. (1954). J. clin. endocr., $14,814$.

Young, H. H., Ward, L. E., and Henderson, E. D. (1954). J. Bone Jt Surg., 36A, 602.

Ziff, M., Scull, E., and Bunim, J. J. (1952). Fed. Proc., 11, 405. $\longrightarrow$ intern. Med., 90, 774 .
Ziff, M., Wilson, H., Scialabba, D., Scull, E., and Glyn, J. (1953). J. clin. Invest., 32, 614.

Zweifel, B. W. (1954). Schweiz. med. Wschr., 84, 447.

Effet antirhumatismal local des esters en position haute et des analogues d'hydrocortisone

RÉSUMÉ

(1) Le t-butyl acétate d'hydrocortisone (F t-Ba) en injection intra-articulaire dans les genoux arthritiques de 171 malades a produit un effet palliatif plus grand et plus durable que des doses identiques d'acétate d'hydrocortisone $(\mathrm{Fa})$ chez environ 60 pour cent des malades. Dans 35 pour cent environ des cas on n'a pas vu de différence et chez environ 5 pour cent des malades l'acétate d'hydrocortisone a été plus efficace.

(2) De façon similaire, deux analogues d'hydrocortisone-9-alpha-chloro hydrocortisone (9-a-c F) et allo-dihydro hydrocortisone (A-d F)-ainsi que deux autres esters en position haute-caprylate d'hydrocortisone (F Cap.) et benzoate d'hydrocortisone (F Benz.) -ont été titrés cliniquement dans 17 cas d'arthrite rhumatismale. Bien que certaines préparations se soient montrées avantageuses ci et là, aucune d'elles n'a produit d'améliorations aussi constantes que le t-butyl acétate d'hydrocortisone. Le benzoate d'hydrocortisone s'est avéré peu pratique car il provoquait de l'irritation synoviale et l'effet de l'allodihydro hydrocortisone a été dans la plupart des cas nettement inférieur à celui de l'acétate d'hydrocortisone.

(3) Bien qu'on ne connaisse pas de raison de cette grande efficacité de certains esters en position haute d'hydrocortisone dans l'atténuation locale des symptômes arthritiques, on croit entrevoir le chemin de $1 £$ découverte des préparations d'hydrocortisone encore plus efficaces par voie intra-articulaire dans les maladies rhumatismales.

\section{ADDENDUM}

Depuis la préparation et la présentation de ce rapport nous avons eu l'occasion de titrer l'acétate de 9-alphafluoro hydrocortisone (9-a-f Fa) par voie intra-articulaire dans 37 cas d'arthrite rhumatismale et d'ostéoarthrite.

Nos résultats confirment que l'acétate de 9-alphafluoro hydrocortisone est un antiphlogistique bien plus fort (noté par Boland et Headley, 1954) et qu'il augmente la rétention sodique (noté par Liddle et coll., 1954). Ce dernier effet semble annuler l'avantage dérivant de sa plus grande puissance, tout au moins pour son emploi intra-articulaire.

Efecto antirreumático local de los ésters en posición alta y de los análogos de hidrocortisona

Sumario

(1) El t-butil acetato de hidrocortisona (F t-Ba) por inyección intra-articular en las rodillas artríticas de 171 enfermos produjo un efecto paliativo mayor y más prolongado que dosis idénticas de acetato de hidrocortisona $(\mathrm{Fa})$ en cerca de 60 por ciento de ellos. En cerca de 35 por ciento de los casos no se observó ventaja alguna y en cerca de 5 por ciento de los enfermos el acetato de hidrocortisona fué más eficaz.

(2) De igual modo, dos análogos de hidrocortisona9-alfa-cloro hidrocortisona $(9-a-c \quad F)$ y alo-dihidro hidrocortisona (A-d F) -así como dos otros ésters en posición alta - caprilato de hidrocortisona (F Cap.) y benzoato de hidrocortisona (F Benz.)-fueron avaluados clínicamente en 17 casos de artritis reumatoide. Aunque a veces algunas de estas preparaciones mostráronse 
ventajosas, ninguna produjo mejorías tan consecuentes como el t-butil acetato de hidrocortisona. El benzoato de hidrocortisona, por causar irritación sinovia, no fué práctico y la alo-dihidro hidrocortisona mostrose en la mayoría de los casos netamente inferior al acetato de hidrocortisona.

(3) Aunque no se conozca la razón de esta gran eficacia de ciertos ésters en posición alta de hidrocortisona en la atenuación local de los síntomas artríticos, el camino parece abierto hacia la descubierta de preparaciones de hidrocortisona aun más eficaces para el empleo intra-articular en las enfermedades reumáticas.
Desde la preparación y la presentacion de este informe tuvimos oportunidad de avaluar el acetato de 9-alfafluoro hidrocortisona (9-a-f Fa) por vía intra-articular en 37 casos de artritis reumatoide y de osteoartritis.

Nuestros resultados confirman el aumento apreciable de la potencia anti-inflamatoria del acetato de 9-alfafluoro hidrocortisona (notada por Boland y Headley, 1954), y el aumento de la retención sódica (notada por Liddle y col., 1954). El último efecto parece anular la ventaja de la mayor potencia, al menos respecto a su empleo intra-articular. 